\title{
Inflationary Forces Prevail
}

\begin{abstract}
T NDERLYING ECONOMIC FORCES are strong, and economic activity continues to accelerate. Production has picked up since last spring but has lagged the growth in demand. In addition to pressure from excess demand, rising costs of production have contributed to rapidly rising prices. Monetary policy, which had been very stimulative in 1967, moved toward restraint early this year. However, fiscal actions have continued to be expansionary, and the prospect of larger than anticipated increases in defense spending threatens the economy with additional inflationary pressure.
\end{abstract}

Investment spending has shown the sharpest advance since mid-1967, with most of the rise being due to an expansion of inventories. Business fixed investment, which has increased since mid-1967 following a sluggish performance earlier in the year, is expected to accelerate in 1968. Consumer spending, while still moderate relative to gains in other years since 1961 , has been adding to the demands on productive resources. Growth in demand for goods and services by the government sector has been rapid, and has contributed to upward pressure on prices by supplementing the buoyant private demand.

\section{Oupputs, Spending and proes}

Real product has increased at a 5 per cent annual rate since mid-1967, following a slowdown early last year. Much of the expansion in output has been due to inventory accumulation, which rose from near zero last spring to an annual rate of $\$ 9.2$ billion in the fourth quarter. Investment in inventories early this year has been prompted to some extent by expectation of higher prices and anticipation of strikes in the steel industry this summer.

Industrial production increased at a 5.5 per cent annual rate from June to February, compared with a 4.6 per cent average gain from 1957 to 1967 . Production moderated early this year because of strikes

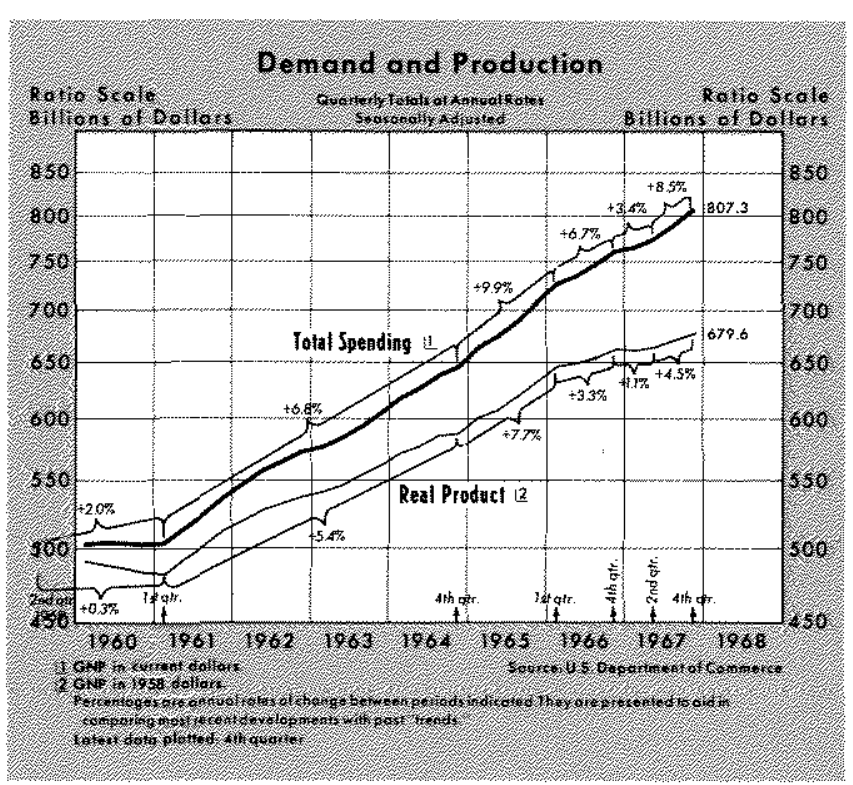


and a probable reaction to the unusually rapid expansion of output in the last two months of 1967.

Employment has grown significantly as the pace of economic activity has picked up. Employment rose at a 4.0 per cent annual rate from last spring to February, following a 2.2 per cent rate of decline over the previous four months. Payroll employment, which was held down by strikes in the fall, has increased, on balance, at a strong 4.2 per cent rate since last spring. By comparison, population of workingforce age has increased at an estimated 2 per cent annual rate.

Personal income rose at a 9 per cent rate from spring to February, reflecting increasing employment and rising compensation. By comparison, income grew at a 6 per cent trend rate from 1957 to

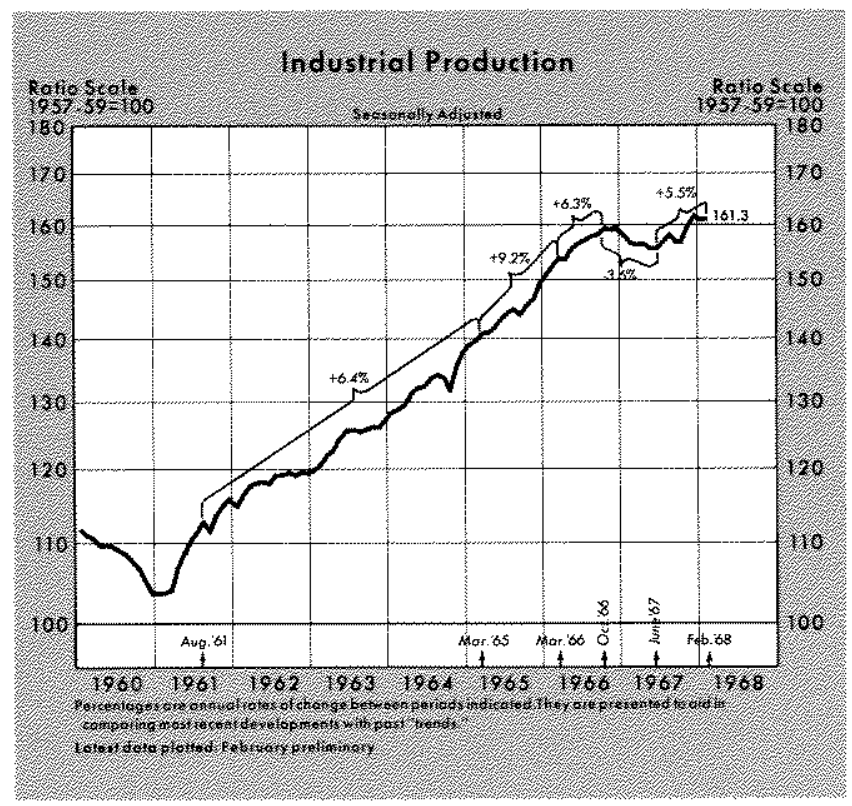

1967. Recent growth in income has been reinforced by increased social security benefits as well as the general expansion in economic activity.

Consumer spending has advanced, in response to income growth. Households are still saving a relatively large portion of their take-home pay, but the recent rapid increases in income have allowed consumer spending to pick up. Retail sales increased at an 8 per cent annual rate from last spring to February, following little change over the previous year. Sales of durables were particularly strong early this year, partly as a result of purchases of automobiles which had been postponed earlier when availability was limited by strikes.

Acceleration of demand and increased costs have placed increasing upward pressure on prices since

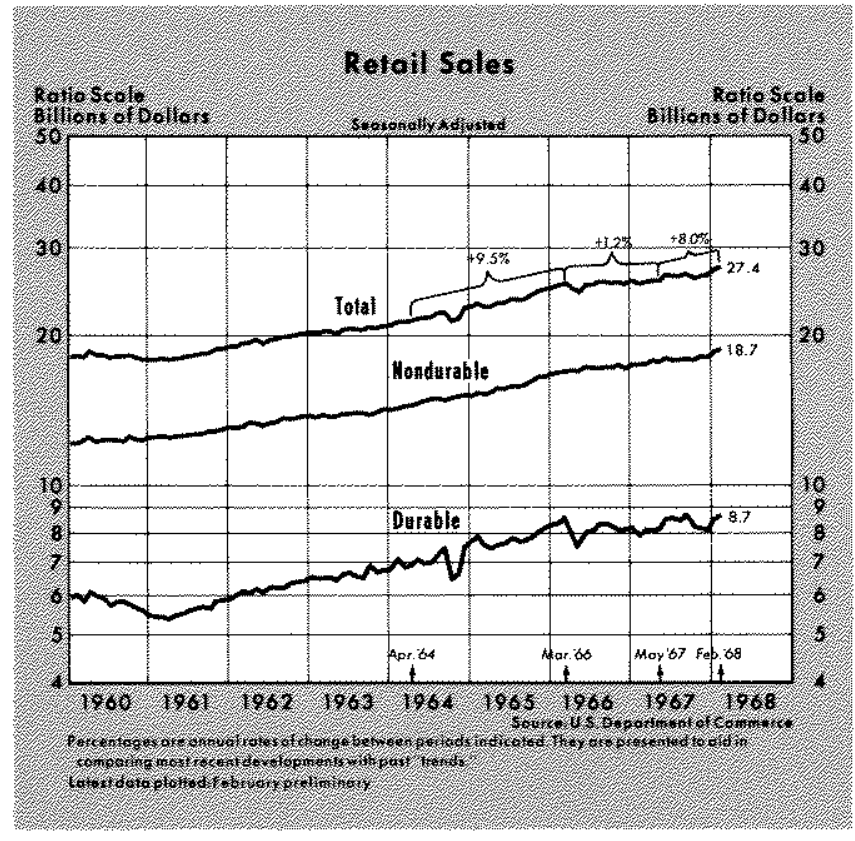

mid-1967. From last July to January, the prices of consumer commodities other than food increased at a 4 per cent rate, up from a 2.2 per cent rate of rise earlier in the year. Food prices, which had declined last fall, rose sharply in December and January. After changing little in the first seven months of last year, wholesale prices of industrial commodities rose at a 3.8 per cent annual rate from July to February.

\section{Monetary and Fiscal Actions}

Growth in most monetary aggregates has slowed during recent months as monetary policy shifted to-

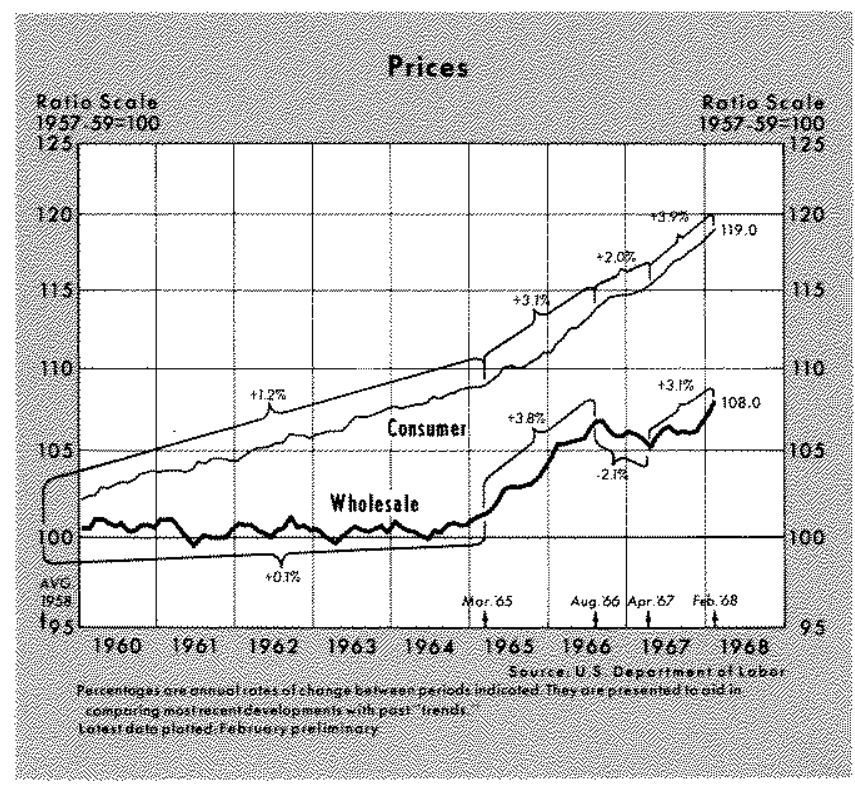




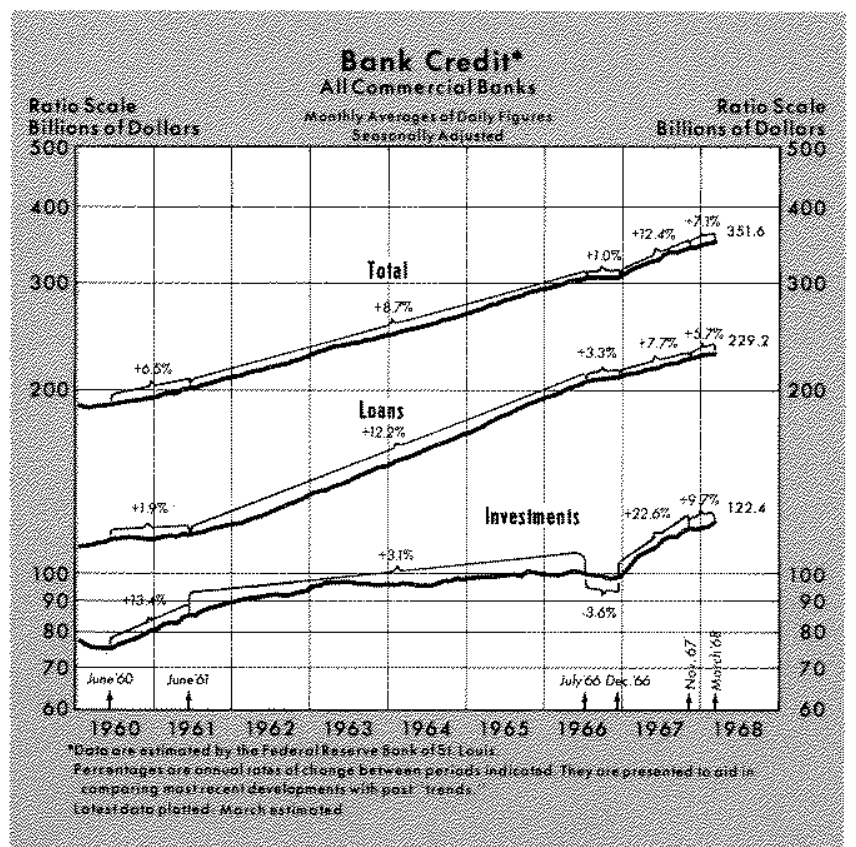

ward restraint. From November to March, the nation's money stock, currency held by the public plus private demand deposits, expanded at a 3.4 per cent annual rate, down sharply from the 8 per cent rate of increase over the previous ten months. Growth in bank credit has also slowed, increasing at an estimated 7.1 per cent rate over the four months ending in March. In contrast, bank credit rose at a 12 per cent rate from December 1966 to November of last year. The slowdown of bank credit over the recent four-month period was associated with a reduced rate at which banks purchased securities.

Fiscal actions continue to be a stimulative force on economic activity. The high-employment budget, which is a measure of discretionary government action, was in deficit at an annual rate of $\$ 11$ billion in the second half of last year, little changed from the first half. The nature of fiscal policy in 1968 depends critically on whether the proposed tax surcharge is adopted and how closely Government expenditures are held to the levels proposed in the budget message. In the absence of a tax increase and with expenditures as proposed in the January budget message, the Government will continue to be as expansionary as in 1967. If defense spending increases beyond present projections, causing total Government outlays to rise, the surcharge would serve to offset some part of the impact of the increased spending, and on balance might do relatively little to moderate the expansionary nature of fiscal actions. A move to reduce expenditures would reinforce the restrictive effect of the income tax surcharge.
The moderation of monetary expansion was primarily designed to curb domestic inflation, but it was also timed to improve international confidence in the dollar. The heavy speculative demand for gold in Europe during the first half of March was based on expectation that the price of gold was likely to rise.

In an attempt to prevent the speculative demand for gold from upsetting the international monetary mechanism, the London Gold Pool ${ }^{1}$ agreed in Washington on March 17 to allow the private price of gold to seek its own level, while the U.S. reiterated its pledge to maintain the price of gold at $\$ 35$ an ounce to foreign central banks. This was designed to insure that the present monetary gold stocks of the world's central banks would continue to be valued at $\$ 35$ an ounce, and thus assure that the international money supply would not be upset by a change in the commodity price of gold. It is hoped that separating the private demand for gold as a commodity from the official demand for gold as a monetary asset will free the present international monetary system from the major shocks of private speculation.

\section{The Composition of Demand}

There have been marked shifts in the composition of demand for goods and services in the period since 1965. Reflecting the war in Vietnam, the portion of resources allocated to government use has risen sharply. Investment spending as a portion of GNP fell sharply in the first half of last year but has increased since. On balance, consumers have accounted for a

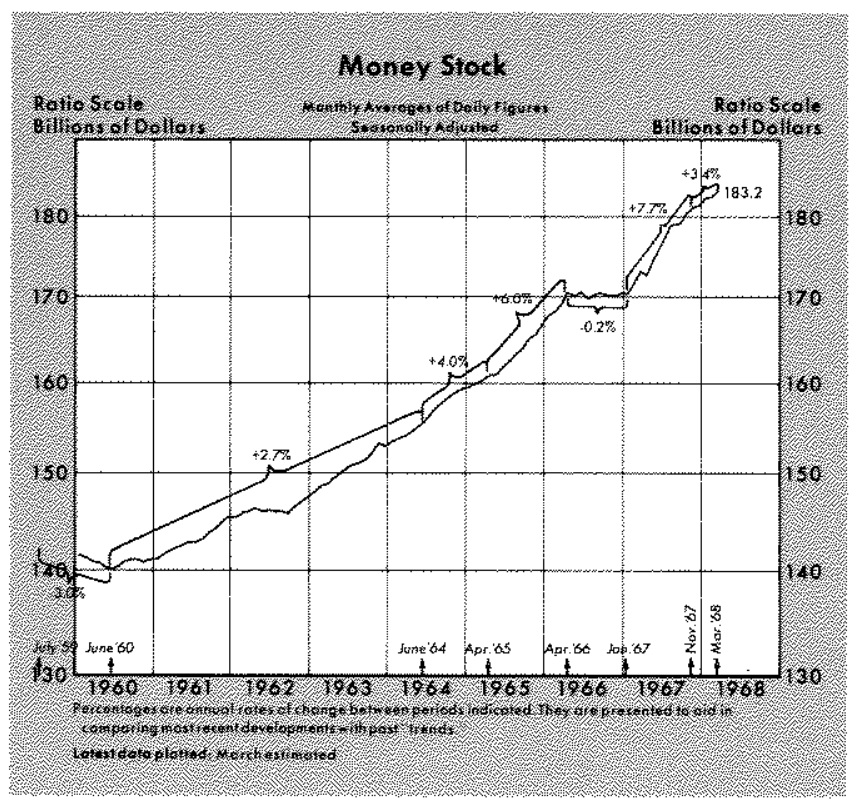

1Belgium, Great Britain, Italy, Netherlands, Switzerland, United States, and West Germany. 
declining portion of total spending since 1965 .

The expansion of inventories since mid-1967 is in line with average performance over the period from 1961 to 1965. In the fourth quarter of last year inventory accumulation accounted for 1.1 per cent of GNP, the same as the average share over the period from 1961 to 1965 . This is in contrast to late in 1966, when a rapid and unsustainable inventory build-up accounted for a 2.4 per cent of total spending.

The pattern of other investment spending relative to GNP has also shifted since 1966. Expenditures for plant and equipment averaged 9.1 per cent of total spending from 1960 to 1963 . Businesses began to accumulate fixed capital at a rapid rate in 1964, and this share rose to almost 11 per cent by 1966 . The sharp addition to capacity became excessive as total demand slowed in late 1966 and early 1967. Fixed investment then moderated, and the share of GNP allocated to plant and equipment fell to 10.4 per cent by the fourth quarter of last year.

In contrast to fixed investment, the share represented by residential construction began to decline early in 1964, after averaging 4.5 per cent of total spending over the period from 1960 to 1963 , and reached a low of 2.7 per cent of GNP late in 1966 . Homebuilding expanded last year and by the fourth quarter accounted for 3.4 per cent of total spending.

Consumer durables accounted for an increasing share of GNP from early 1961 to early in 1966, rising from 8.3 in the first quarter of 1961 to 9.9 per cent in the first quarter of 1966. As prices began to accelerate, consumer spending for durables moderated. Since early 1966 durables have declined as a portion of total spending, falling to 9.1 per cent by the fourth quarter of last year. Consumer nondurable purchases have declined relative to GNP since early 1961, falling from 30.6 per cent in the first quarter of 1961 to 27.3 per cent in late 1967 . The share going to services has changed little since 1960 and remains near 25.5 per cent.

As defense spending accelerated after mid-1965, the portion of resources allocated to defense rose sharply from 7.3 per cent in the second quarter of 1965 to 9.4 per cent in the second quarter of 1967. Growth in defense spending has moderated since early last year, and defense expenditures as a portion of total spending have declined slightly. The portion of demand accounted for by defense is small relative to the Korean War period when defense claimed as much as 13.5 per cent of GNP. Federal nondefense purchases of goods and services have changed little relam tive to total spending since 1960 , accounting for about 2.3 per cent of GNP. Spending by state and local government accounted for a fairly stable portion of demand from 1960 to 1965 . The share increased from
10.2 per cent in early 1966 to 10.9 per cent a year later, and has changed little since.

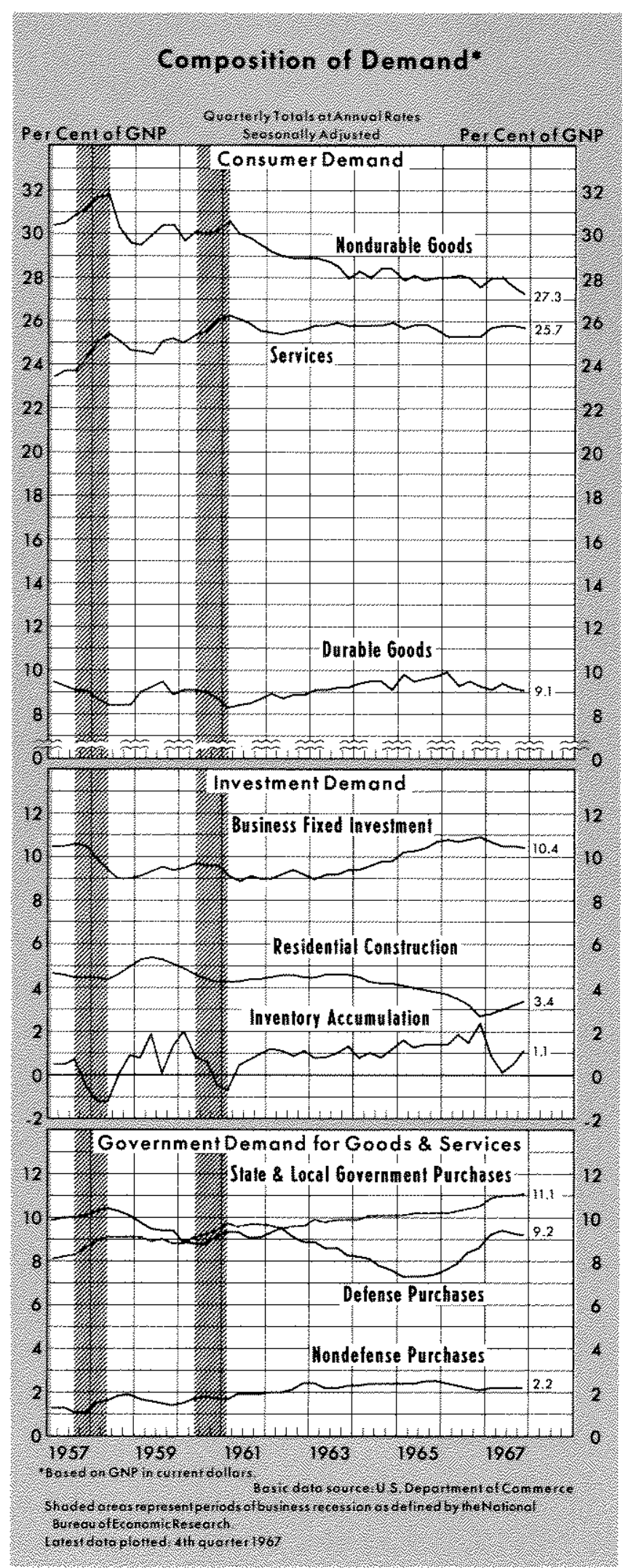




\section{Summary}

Following a period of adjustment in early 1967 , private demand for resources has expanded at a rapid rate. Coupled with heavy defense requirements, the expanded demand has become excessive. Price increases have accelerated, threatening the sustainability of current economic growth and contributing to a weakening of the position of the U.S. economy in the international market.

The excessive demands were fostered by stimulative monetary and fiscal developments. In recent months monetary expansion has slowed, and now serious consideration is being given to adopting more restrictive fiscal actions.

\footnotetext{
UBSCRIPTIONS to this bank's ReviEw are available to the public without charge, including bulk mailings to banks, business organizations, educational institutions, and others. For information write: Research Department, Federal Reserve Bank of St. Louis, P. O. Box 442, St. Louis, Missouri 63166.
} 